\section{Vietnam Journal of Agricultural Sciences}

\title{
Improving Agricultural Value Chain Financing: A Case Study of Seng Cu Rice Chain in Lao Cai Province, Vietnam
}

\author{
Bui Thi Lam ${ }^{1,2}$, Tran Huu Cuong ${ }^{2}$, Le Thi Thanh $\mathrm{Hao}^{2}$ \& Philippe \\ Lebailly ${ }^{1}$
}

${ }^{1}$ Gembloux Agro-Bio Tech, University of Liège, Gembloux 5030, Belgium ${ }^{2}$ Faculty of Accounting and Business Management, Vietnam National University of Agriculture, Trau Quy, Gia Lam, Hanoi 131000, Vietnam

\begin{abstract}
Nowadays, agricultural value chain financing (AVCF) is considered an effective agricultural financing approach in the world; however, its prevalence is still limited in developing countries like Vietnam. This paper aimed to analyze the financial gap between the demands and the actual credit obtained of the Seng $\mathrm{Cu}(\mathrm{SC})$ rice chain participants in Lao Cai province, Vietnam. Cross-sectional data were collected from 160 face-to-face interviews with SC rice producers and in-depth interviews with 31 other stakeholders involved in the chain (demand-side) as well as the representatives of district-branch banks (supply-side) in 2016-2017. Overall, almost all chain actors had high financial demands, especially upland rice producers and the leading chain actor (Tien Phong Cooperative). However, they faced many credit constraints related to the strict risk-avoidance strategy and the collateral requirement of the banks. Even though the SC rice chain confirmed its high potential and many supportive linkages among participants were developed, the decision-making of banks on credit disbursements still depended on the individual capability of each chain actor rather than the entire chain. Thus, some recommendations for policymakers, producers, and agribusinesses are suggested to enhance the financial sources going in the chain and the effectiveness of chain actors in the locality. Specifically, banks need to assess the creditworthiness of farmers and agribusinesses through the enhancement of repayment capability; while the public sector needs to enact new regulations encouraging the participation of banks in the chain.
\end{abstract}

\section{Keywords}

Agricultural value chain finance, Seng $\mathrm{Cu}$ rice, rural finance, Lao Cai province

Received: June 12, 2020 Accepted: October 15, 2020

Correspondence to btlam@vnua.edu.vn

\section{Introduction}

In recent years, the studies on AVCF have become strangely attractive because of their effectiveness in many fields, including 
economics, society, and environment. In short, AVCF encompasses the flow of products, finance, agricultural knowledge, and market information from producers to consumers. Coates et al. (2011) suggest that the most suitable model for agricultural development is to approach the sector by sub-sectors and meet tailor-made financial needs throughout that specific value-chain. The comprehensive valuechain approach might be the more inclusive and increased breadth and depth of agricultural finance (Miller \& Jones, 2010). Indeed, this approach provides tailored services and products along a specific value chain in order to reduce the financial cost and risk, enhance the effectiveness of the chain actors as well as increase the competitiveness and sustainability of the whole chain (Miller \& Jones, 2010; Miller, 2012; AfDB, 2013; HLPE, 2013). Under the AVCF approach, small farmers are likely to gain greater benefits and fewer risks (Miyata et al., 2009; Saigenji \& Zeller, 2009; Olomola, 2010; De La O Campos et al., 2018).

It is evident that small farmers and agribusinesses in developing countries are still excluded from formal financial sources and the AVCF might enable their inclusion. Rapsomanikis (2015) concludes that the globalization of the food chains has further isolated the small-scale farmers and they gradually become unviable economic units. They seem to be excluded not only from financial markets but also from the general development stream of humanity. In addition, financial suppliers rarely have full insight into the heterogeneous demands of rural households and agribusinesses because the process requires cost and is time-consuming. As a result, credit services are often mismatched with the needs of the borrowers and/or are used ineffectively. The AVCF approach shows promise of offering a systematic solution to achieve the triple goals: connect the poor smallholders with their community and society, and obtain both financially and ecologically sustainable livelihoods from farm- and non-farm activities.

In the Northern Midlands and Mountain (NMM) of Vietnam, agriculture plays an essential role in the local economy because it is the main livelihood of nearly $90 \%$ of the rural population (GSO, 2018). Among factors affecting agricultural development, lack of capital and difficulty in market access are the two strongest barriers of farming actors (ibid). These problems can be handled significantly under the effective value chain financing approach thanks to the diversity of financing relationships existing in the chain. Unfortunately, the application of AVCF in the NMM region is still very limited and there is a lack of systematic research on this topic in mountainous areas of the country.

In this study, the Seng $\mathrm{Cu}$ (SC) rice value chain in Lao Cai province was chosen to represent the research on AVCF in the mountainous areas of Vietnam. The paper aimed to analyze the financial demands of chain actors and credit constraints hindering their performance as well as the chain's development.

\section{Methodology}

\section{Research sites}

Lao Cai was chosen for the research on the montane rice sector because the province had typical social, economic, and political characteristics representing the NMM region. The province is located in the Northern Midlands and Mountain (NMM), the largest ecological area, concurrently, the homeland of the majority of the poor in Vietnam (GSO, 2017). In addition, the province is also endowed with favorable natural condition for rice growing. More detailed, according to GRiSP (2013), rice planted in low-latitude, high solar radiation, and cool temperature tends to achieve higher productivity and quality. Indeed, Seng $\mathrm{Cu}$ Lao Cai is the unique kind of rice recognized as the special and safe product of Lao Cai province (Figure 1c) and is often one of the highest selling price rice in the national market. Regarding cereals, rice cultivating is often prioritized over maize, so most cropping land is devoted to rice cultivation (Figure 1b) where it is possible to harvest rice thanks to water availability.

There are two main typical agro-ecologic zones in Lao Cai, upland and lowland. In uplands, rice is planted in small terraced plots on 
hillsides with limited water resource, almost without public irrigation. On the contrary, lowland rice is cultivated in flat fields and harvested twice per year. Producers here also take advantage of the well-constructed irrigation system (Figure 1b) and many productive infrastructures.

Four largest Seng $\mathrm{Cu}$ rice production communes in two different ecological zones (i.e. upland versus lowland, corresponding to rainfed versus irrigated) were selected for the study, including: (i) two lowland communes, namely, Muong Vi and Ban Xen (green 1 and 2 on the map, respectively); and (ii) two upland communes called Nam $\mathrm{Lu}$ and Lung Khau Nhin (orange 3 and 4 on the map, respectively) (Figure 1a).

\section{Data collection}

Both secondary and primary data were collected to conduct qualitative and quantitative analyses. The former analysis was applied to explore the interactions and relationships existing among participants in different product channels. Furthermore, their perspectives about the policies related to agricultural supports and linkages were precisely recorded. The latter one was used to collect data from the household survey and in-depth interviews to analyze SC rice production cost of the producers and its financial sources. Data in the study are elaborately described below.

\section{Secondary data collection}

In this study, archival research gathered various previous reports and relevant official statistics about the socio-economic situation of Lao Cai province and the NMM region. This step helped to identify proper research sites and representative agricultural products for the study (Seng $\mathrm{Cu}$ rice). Moreover, this data source also supported and/or compared the primary data collected from the fieldwork in the next steps. Moreover, the second type of documents which served literature review and discussion, etc.

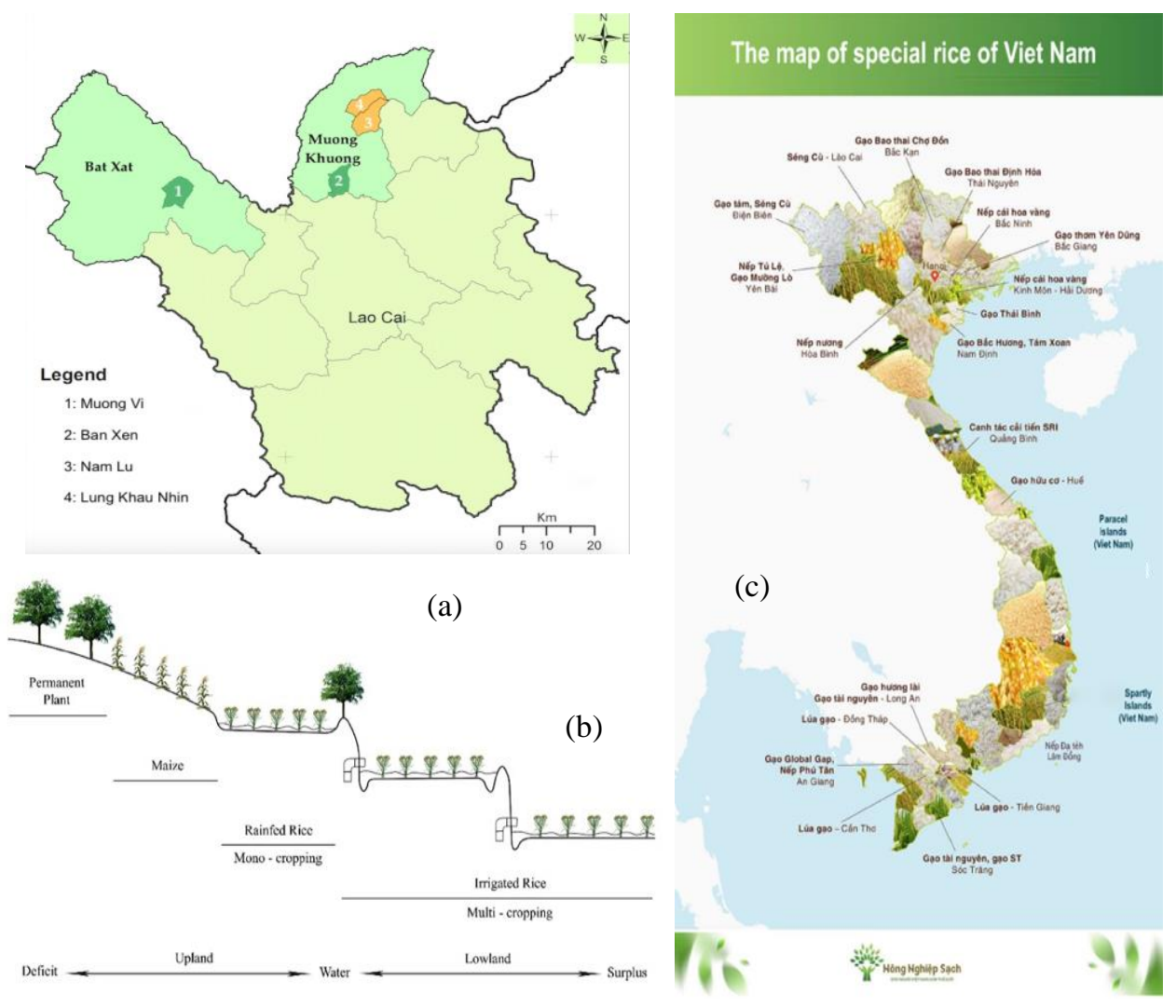

Figure 1. Description of the research sites

Source: Figures 1a and 1b are author's own elaboration; Figure 1c is cited from Vi Huyen (2018). 
was also collected. It consisted of articles, books, consultancy reports, technical notes, project reports, government official reports, and policy documents, etc.

\section{Primary data collection}

Participant observation is defined as an ethnographic research approach in which the researcher's participate in the lives of the local people while also maintaining an appropriate distance in order to develop ongoing relations with the people in it, and actively reflects on what is going on (Emerson et al., 1995; Fetterman, 2009). However, this study prioritizes the studied issues among the ongoing local background due to the limitation of time and funding. This method plays a pivotal role to what extent, in the evaluation of the validity of data collected through the interview (Kelly, 2005). It is important to note that finance is usually a sensitive and delicate topic in any society.

The household survey was conducted based on the structured questionnaire and face-to-face interviews to capture: (i) the specific households' characteristics; (ii) SC rice farming practices, input management, and its financing sources; (iii) the costs and income generated from SC rice production; and (iv) the farmers' feedbacks on banking credit and linkages among chain actors.

In this study, the sampling size of household survey was determined through the underlying Cochran's (1977) formula:

$$
\mathrm{n}=\frac{\mathrm{Z}^{2} x \boldsymbol{p} x(1-p)}{\mathrm{e}^{2}}
$$

Where: $\mathbf{n}$ is the sampling size; $\mathbf{Z}$ is the statistical value in accordance with the level of confidence desired in the normal curve (e.g. $Z=$ 1.96 for $95 \%$ level of confidence); $\mathbf{p}$ is the estimated proportion of SC rice producers in the district population $(\mathrm{p}=0.5)$; and, $\mathbf{e}$ is the desired level of precision $(7.75 \%)$. Based on these, the sampling of 160 households was identified, including 80 upland and 80 lowland SC rice producers.

In-depth interviews were conducted with officials working at the Department of Agriculture and Rural Development at three administrative levels (provincial, district, and communal) and clerks working at the Vietnam
Banks for Agriculture and Rural Development (VBARD) and the Vietnam Bank for Social Policy (VBSP) in Muong Khuong and Bat Xat districts. More importantly, 31 interviews with stakeholders involved in the chain, including input suppliers, small collectors, large collectors, and retailers were conducted through convenience and judgment sampling methods.

Group discussions were held for 8 to 10 household participants to identify the current local rice farming practices; the reasons why farmers would not like to apply advanced practices; and the main difficulties and how to overcome them. In addition, the role of SC rice in household's economic opportunities, livelihood, and culture was also sketched out in these group discussions.

\section{Data analysis}

In order to evaluate the performance of chain actors and the finance of a particular value chain, it is necessary to have a good understanding of their costs and benefits. Based on the performance and the financial flows in the chain, the weak actors in the chain were identified; and then, recommendations on how to upgrade the actors' capability in particular, and on how to strengthen the whole chain in general were made.

The collected data in this study were analyzed through indicators of the value-added analysis by using the program Value Links 2.0 (Springer-Heinze, 2018). These three leading indicators are defined as follows:

(i) Intermediate Cost (IC) includes the total value of purchasing variable inputs (goods and services) used in agricultural production cycles.

(ii) Gross Output (GO) is the total value of the main and by-product outputs generated.

(iii) Value Added (VA) is the total worth created on agricultural production and calculated by the following equation: $\mathrm{VA}=\mathrm{GO}-\mathrm{IC}$

To test whether the differences between the groups mentioned above were significant, we used descriptive statistics, the Student's T-test. In this study, the T-test was done to examine the statistical hypothesis on the role of credit access in agricultural production through the Intermediate Cost (IC), Gross Output (GO), and Value-added (VA) indicators. 


\section{The Results and Discussion}

\section{Financial demands of SC rice chain participants}

Main actors participating in the Seng $\mathrm{Cu}$ rice value chain consisted of: (i) producers (upland and lowland); (ii) input suppliers; (iii) small collectors; (iv) large collectors (Tien Phong Cooperative: TPC and others); and (v) retailers. Among the chain participants, producers and large collectors played important roles in the quality management of rice as well as in the development of the chain. The growers determined the yield and quality of paddy rice in the production phase, while the large collectors performed multiple post-harvesting tasks (e.g., collecting, storing, processing, trading, and delivering) and decided on the quality of milled rice and the value-addition generated. Notably, TPC was considered the leading actor due to their remarkable contributions to the management of the quality of paddy rice along the marketing channel as well as innovation to gain more value addition of relevant participants.

Figure 2 reveals the financial flows (internal and external financing) and the commodity movement (inputs and paddy rice) through the $\mathrm{SC}$ rice chain. Notably, credit demands of SC rice chain participants included short-term credit for operational cost and long-term credit for fixed assets. Overall, each chain player had specific credit demands depending on their available cash accumulation/equity $(+)$ and costs required from their economic activities in the chain (-). Among the external financing going from outside the chain, bank credit played the most important role due to its availability in terms of the large loanable funds, flexible duration (short- and long-term), and low interest rates. As the weakest financial point, internal financing within the chain was mainly devoted to producers through vertical and horizontal linkages among participants.

Credit demands of SC rice growers typically consisted of the following two types: short-term credit to buy commercial inputs (certified seeds and fertilizers) and long-term credit to purchase fixed assets. Besides the demands for seasonal loans for buying inputs, in lowland, SC rice farmers needed long-term loans for buying agricultural machinery, such as tillage machines, reapers, threshers, millers, and dryers. In uplands, producers wanted to borrow money to create a self-made irrigation system with the cost varying from 5 to 12 million VND because of the absence of public irrigation there, which was only invested in lowland areas. Besides this, upland producers needed long-term credit to buy cattle for land preparation, traction, and transportation. They also wanted to repair the storing place to better ensure the quality of the paddy.

The second most important actor in SC rice chain was TPC, who was considered the leading

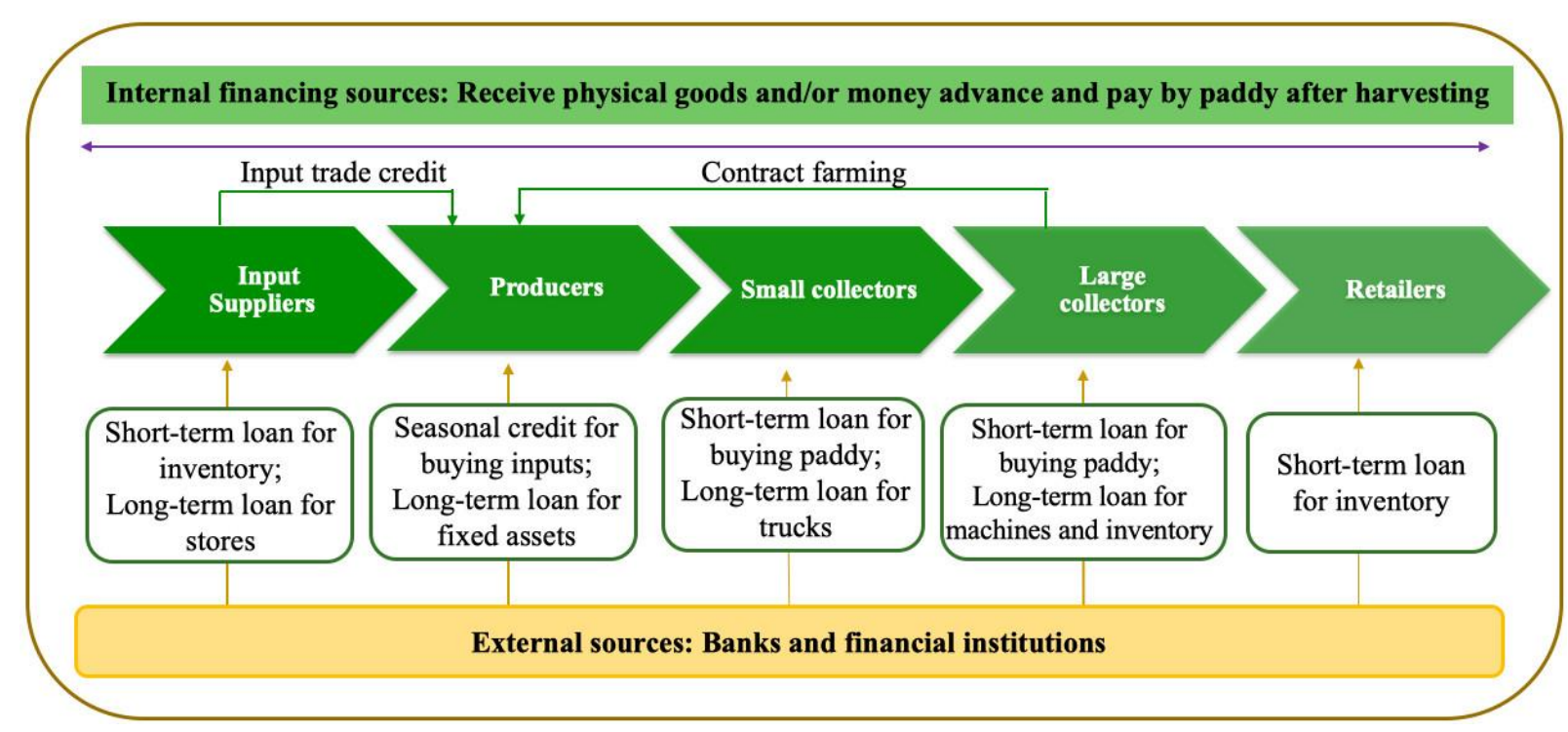

Figure 2. Financial needs of key actors in the SC rice value chain in Lao Cai 
Table 1. Cost-and-Benefit Analysis of the TPC and large collectors in 2017

\begin{tabular}{lcc}
\hline \multicolumn{1}{c}{ Products } & TPC & Other large collectors \\
\hline I. Cost and benefit generated in a business year & & 800 \\
\hline Paddy purchased (tons) & 700 & 11,575 \\
Total cost (mil. VND) & 10,631 & 14,240 \\
Total revenue (mil. VND) & 16,085 & 2,665 \\
Total value added (mil. VND) & 5,454 & 17.80 \\
\hline II. Cost and benefit generated from 1kg of dried paddy converted & & 14.47 \\
\hline Unit selling price (1000 VND) & 22.98 & 3.33 \\
Intermediate costs (1000 VND) & 15.19 & 2.72 \\
\hline 1. Value added (1000 VND) & 7.79 & \\
$2 . \quad$ Gross profit (1000 VND) & 5.48 & \\
\hline
\end{tabular}

Source: In-depth interviews (2017)

player. TPC exploited the trademark "Lao Cai Seng $\mathrm{Cu}$ Rice" and served high-end market segments nationwide. In doing so, TPC paid attention to the management of the quality of rice in both production and processing stages. In the production phase, TPC signed up contractfarming with producers and funded high-quality inputs in advance, such as certified seeds, organic pesticides, and special rice fertilizers. In addition, TPC assigned one technician to collaborate with farmers and take charge of disease control. TPC collected fresh paddy at the fields to prevent farmers from mixing ordinary paddy with Seng $\mathrm{Cu}$ as well as to prevent sideselling, which used to take place in the past. In the processing phase, TPC invested modern processing machinery such as dryers, millers, polishers, wrappers, and vacuum-packers. This state-of-the-art processing technology enabled TPC to achieve a higher rate $(66 \%)$ of milled rice compared to that of the large collectors (60$65 \%$ ). To gain more value on Seng $\mathrm{Cu}$ rice, TPC continuously innovated to have a diversity of marketable products, such as white rice, brown rice, germ rice, alcohol (main products), broken rice, and bran (by-products); while other large collectors only focused on one commercial product, the white rice.

The portfolio of marketable products explained the significantly higher value addition of TPC over that of other large collectors (Table
1). For example, although TPC collected less paddy rice ( 700 versus 800 tons), TPC's total value-added investment enabled them to gain twice more than the average collector, 5.5 and 2.7 billion VND in 2017. SC rice in TPC's marketing channels had better quality, which partly explains the difference in selling prices and the higher value addition and profit of TPC. In turn, farmers participating in this channel also gained higher value addition. Indeed, among the six channels, farmers participating in the TPC channel gained nearly $12,000 \mathrm{VND}$ per $\mathrm{kg}$ of rice, followed by $11,200 \mathrm{VND}$ per $\mathrm{kg}$ in the channel (3) of the small and large collectors (Lam et al., 2019a). Given the performance and innovation, TPC strongly needed short-term loans for buying inputs, which were financed in advance for farmers, and for collecting fresh paddy at the harvest time in May - July and September - October.

Almost all large collectors owned the out-ofdate processing machine system, which led to a reduction of recovery rate, as mentioned above, and a decline in the quality of rice milled compared to TPC. They desired to get long-term loans to replace the old machinery by the modern ones to improve the quality of rice, and then, reach larger markets outside the province and region. Currently, their products were not packaged carefully and high-quality, so, their shelf life was 2-3 weeks only, while that of TPC, 
the standard package, was 3 months. In addition, they also needed loans to improve their storehouse, in particular, reducing the losses they encountered due to the presence of various pests in their storehouse.

Small collectors mostly living in upland areas collected paddy rice ordered by the large collectors. They were better-off producers. They needed money from the bank to buy small trucks that would allow them to collect more paddy per trip so that they could reduce their transaction cost, at the same time, keeping them safe when traveling in mountainous areas. They also applied for VBARD's loans to improve the paddy rice storage conditions of their storehouse. Retailers had good financial availability; therefore, they nearly had not had a high credit demand.

\section{Internal financing among key chain actors}

This study identified two internal financing sources of the SC rice value chain: Common Interest Groups (CIGs) and Contract Farming, which were in parallel with horizontal and vertical linkages in the chain. The volume of funding was still small, and only some producers benefited from the chain.

\section{CIGs - a horizontal linkage}

CIGs are considered a socio-economic development instrument, which is called Economic Interest Group (EIG) by FAO \& ADA (2016). EIG collaborations create a financial and non-financial ecosystem and a well-served infrastructure to meet value chain development requirements and/or local economy. In this system, both government and banks also participate in meeting the financial demands and other supportive activities in the chain; thus creating a multi-stakeholder relationship to support each other.

CIGs were vertical links of 10 to 20 Seng $\mathrm{Cu}$ rice producers. This model was more prevalent in uplands than in lowlands. About 333 Seng $\mathrm{Cu}$ rice-growing households belonged to 21 CIGs in the two communes of Muong Khuong district. Among the CIG members, $73 \%$ were classified as poor. CIG members gained at least one of the three following benefits:
Firstly, they often shared their work in the field (e.g., preparing land, transplanting, and managing diseases, etc.), discussed and learnt agricultural knowledge and advanced technologies together. They reduced labor costs because of shared labor in transplanting and harvesting activities. Besides, working together allowed most rice plants to grow at the same time/stage (from vegetative, reproductive, to ripening), thus maximizing the use efficiency of water, harvesting machines, and other related things. Altogether, this shared labor among farmers resulted in higher productivity and better quality of paddy rice and reduces paddy losses.

Secondly, some CIGs were also social networks, in which farmer members could borrow money for urgent needs without paying interest from other members. It was selfmanaged and called the credit revolving fund (FAO, 1995). Many CIGs also took advantage of the "buy together, sell together" method (i.e., collective marketing), and obtain better prices based on the increase of bargaining power in the commercial transactions and higher discounted rate due to buying in bulk. Clearly, CIGs contributed to increased profits of farmer members in general and SC rice producers in particular.

Thirdly, farmer members benefited from CIGs by having improved access to and participation in productive services, such as extension and contract-farming with enterprises (e.g., with TPC and Muong Khuong Cooperative). They also benefited from technical training provided by the enterprise linkage.

Apart from many advantages of this vertical linkage, some CIGs in SC rice chain still had existing drawbacks. Some leaders of CIGs found it challenging to tackle/resolve conflicts arising between poor and non-poor members. Non-poor farmers complained about the non-diligence of poor members to conduct a common mission of the group. By contrast, poor farmers noticed unfriendly behaviors of higher-income farmers, which hindered them from proactively connecting with others. Hence, it is necessary to conciliate and create a supportive relationship among group's members by the group leader. 
Vertical linkages between farmers and enterprises

TPC signed contracts with 57 producers in Muong $\mathrm{Vi}$ commune, Bat Xat district. If producers requested inputs such as certified seeds, organic pesticides, and fertilizers, TPC would prefund their requests. Miller \& Jones (2010) called this internal financing source as contract farming or forward contract. Unfortunately, limited working capital of TPC hindered them from prefunding inputs and purchasing fresh paddy from farmers. In 2017, TPC collected 700 tons of paddy rice, which used less than $30 \%$ of TPC's machinery capacity invested. Because the machinery was underutilized, the depreciation cost was relatively high and the profit was low. To fully utilize the plant capacity, TPC needs to increase its harvesting and collection of paddy rice by increasing its equity, so it could sign more contracts and fully meet the prefund requests of producers. But presently, TPC lacks the financial capacity to contract a more significant number of farmers.

Another enterprise participating in the chain is the Vietnam-Japan Fertilizer Company (VJF). VJF made contracts with SC rice producers in Ban Xen commune, Muong Khuong district. VJF provided fertilizers (with technical assistance as to when was the right time to apply, what was the right type, and how was the right application done). To access this in-kind credit, growers first registered the land area in which they planned to cultivate SC rice with the communal authorities; next, they indicated the quantity of fertilizers that they would need for the upcoming cropping season. Following that, the assigned local authorities examined their land and desired fertilizers. After this assessment, the communal center then confirmed and guaranteed that the SC rice producers were included. Finally, the communal officials signed a contract with VJF. The contract stipulated that the rice producers would receive fertilizers, and in turn, payback after harvest.

In total, VJF provided 5 tons of rice fertilizers for 10ha of Seng $\mathrm{Cu}$ rice in the commune. This type of farmer-engagement by VJF is termed the Input Trade Credit enterprise
(Miller \& Jones, 2010). Besides the advantages of having good quality fertilizers, the borrowers also received technical assistance on disease control and sustainable farming practices from company technicians. Most respondents who contracted with VJF stated that the learning they had from the technical assistance enabled them to reduce the amount of fertilizers and the cost by close to $8 \%$. The JVF fertilizers contributed to increasing their crop production by almost $15 \%$.

\section{External financing of SC rice chain}

In Lao Cai province, two state-owned banks, VBARD and VBSP, dominated the formal rural credit market. These two banks were strongly supported by the Government to obtain the goals of agricultural development and poverty reduction. VBSP provided preferential credit packages to low-income customers following government regulations, while VBARD provided credit to customers with higher incomes. VBARD accounted for the largest share in terms of the outstanding loan, while VBSP had the highest number of household clients. For example, in the formal and semi-formal rural markets of Lao Cai, the outstanding loan of VBARD and VBSP accounted for $81.2 \%$ and $18.5 \%$ of the total credit volume, respectively. Moreover, $64 \%$ of households borrowed from VBSP and $34 \%$ borrowed from VBARD. Under the rural credit market like the quasi-monopoly, the rural customers were restricted in the choice of formal financial services and could not do anything about the quality of services offered by the banks (Lam et al., 2019b). Indeed, our findings indicate that almost all chain participants had high financial demand; however, they face many obstacles to fulfill those demands.

Among 160 Seng $\mathrm{Cu}$ rice producers, 136 households (85\%) applied for a loan application at banks and only 97 households of them (71\%) were able to access credit (Table 2). On average, their obtained credit satisfied $67 \%$ of the desired total amount. More specifically, lowland farmers obtained more credit from these banks than upland producers, 32.1 million and 21.1 million, respectively. The reasons are explained as mentioned above, upland farmers face more obstacles of credit access related to collateral (land use certificate) and human capital (education, skills, and ethnicity, etc.). 
Table 2. Credit access of key Seng Cu chain actors in Lao Cai

\begin{tabular}{|c|c|c|c|c|c|}
\hline \multirow[b]{2}{*}{ Actor } & \multicolumn{2}{|c|}{ Interviewees have ... } & \multicolumn{3}{|c|}{ Credit size (mil. VND) } \\
\hline & $\begin{array}{l}\ldots \text { credit } \\
\text { demand }\end{array}$ & $\begin{array}{l}\ldots \text { credit } \\
\text { access }\end{array}$ & $\begin{array}{l}\text { Volume } \\
\text { desired }\end{array}$ & $\begin{array}{l}\text { Volume } \\
\text { Received }\end{array}$ & $\begin{array}{c}\text { Satisfied extent } \\
(\%)\end{array}$ \\
\hline Producers $(n=160)$ & 136 & 97 & 41.2 & 26.6 & 67.2 \\
\hline Small collectors $(n=9)$ & 6 & 5 & 120 & 80.0 & 83.3 \\
\hline Large collectors $(n=11)$ & 10 & 10 & 1,000 & 750 & 75.0 \\
\hline $\operatorname{TPC}(n=1)$ & 1 & 1 & 6,000 & 2,000 & 33.3 \\
\hline Retailers $(n=12)$ & 8 & 6 & 200 & 150 & 75.0 \\
\hline
\end{tabular}

Source: Household survey (2016-2017)

Without formal credit access, producers fell in the four following scenarios: (i) investing lower as the dosage recommended by local extension; (ii) using mainly home-made inputs, which often have lower quality than commercial ones, especially seeds; (iii) buying inputs with later repayment; and (iv) borrowing money from moneylenders with high-interest rates. The findings show that the investment in SC rice production of lowland growers was twice as high as that of upland growers (Table 3). Nearly half of the lowlanders and three-fourth of uplanders confirmed that they could not apply farming practices as recommended due to financial shortage, which leads to sub-optimal use of their inputs regarding timing, quantity, and distribution. As a result, irrigated lowland rice often yields higher than upland rice, 5.3 and 4.4 tons ha $^{-1}$, respectively.

Concerning the self-financing source of upland farmers, notably, they had a few cash accumulations from the previous seasons $(9.3 \%)$. Therefore, they used mainly home-made inputs (57.1\%). For example, $56 \%$ of the upland growers used 'self-produced' seeds, and they exchanged these with other local producers (22\%). It means that only $22 \%$ of them purchased certified seeds as compared to $85 \%$ of lowland producers. It is evident that the quality of seeds directly influences the quality and productivity of paddy rice. Although many upland growers knew about the role of the SC rice seed, they could not afford the certified seeds because of their high price $(80,000-130,000 \mathrm{VND} / \mathrm{kg}$ ). Similarly, upland producers used more manure and a small quantity of chemical fertilizers. Meanwhile, lowlanders overused the chemical inputs (fertilizers and pesticides) to maximize the paddy yield.

There were $14.6 \%$ and $8.8 \%$ of the total upland rice cost funded from banks and informal lenders (cash) and enterprises and input suppliers (in-kind credit), respectively. In practice, most loans obtained by upland farmers were small and long-term loans, from 10 to 20 million VND, which were provided by VBSP and VBARD. These loans helped them to buy a cow (accounting for $70-80 \%$ of borrowed money) or to improve a self-made irrigation system. The remaining money was often spent on consumption, followed by agro-inputs, including $\mathrm{SC}$ rice seeds. As a result of low investment, the agricultural productivity of SC rice in the uplands remained low. The upland farm households were in debt, and, many of them were worried about their debts when the repayment date approached, implying that the bank faced high non-repayment risks.

Lowlanders obtained a balanced structure among four financing sources, varying from nearly $20 \%$ to $25 \%$ (Table 3). Clearly, lowlanders obtained more credit from banks and input suppliers. Our survey reveals that upland farmers suffered from higher interest rates 
Table 3. Seng Cu rice production and financing sources of producers in 2016

\begin{tabular}{lccc}
\hline \multicolumn{1}{c}{ Items } & $\begin{array}{c}\text { Terraced uplands } \\
(\mathrm{n}=80)\end{array}$ & $\begin{array}{c}\text { Irrigated lowlands } \\
(\mathrm{n}=80)\end{array}$ & $\begin{array}{c}\text { All } \\
(\mathrm{n}=160)\end{array}$ \\
\hline Total intermediate cost (1000 VND/ha/year) & & 3,426 & 2,533 \\
\hline Seeds & 1,641 & 7,025 & 5,750 \\
Fertilizers & 4,476 & 4,088 & 2,649 \\
Pesticides & 1,209 & 2,458 & 1,450 \\
Operational services & 441 & 16,997 & 12,381 \\
\multicolumn{1}{c}{ Total } & 7,766 & & 18.9 \\
Source of investment (\%) & & 28.4 & 38.5 \\
\hline Cash accumulation & 9.3 & 25.6 & 23.5 \\
Home-made inputs & 57.1 & 26.9 & 15.8 \\
Credit from banks and informal actors & 14.6 & 18.4 & 3.3 \\
Credit by enterprises and input suppliers & 8.8 & 0.7 & \\
Gov. subsidies in seeds and fertilizers & 10.2 & & \\
\hline
\end{tabular}

Source: Household survey (2016)

charged by local input suppliers than lowlanders. The reasons come from their distance: lowland farmers lived close to Lao Cai city, meanwhile upland ones lived in remote areas and the poor infrastructure led to higher transaction costs. On average, the interest rate charged to lowlanders was $1.5-2 \%$ per month, meanwhile, that of uplanders was 3-5\% per month. Under their loan use structure, the interests on these credits accounted for $12 \%$ and $10 \%$ of the total SC rice production cost in uplands and lowlands, respectively. It means that formal credit constraints undermine the profit of upland producers and keep them still living in poverty.

Most upland producers belonging to the ethnic minority people received a subsidy from the Government (Program 135). In the year that the survey was conducted (2016), farm households received all seeds of SC rice based on their registered rice-growing area and $8 \mathrm{~kg}$ of NPK per sao $\left(1 \mathrm{sao}=360 \mathrm{~m}^{2}\right)$. Its average value was 707,000 VND per household, accounting for $10 \%$ of the total production cost. However, these certified seeds mostly came too late compared to the planting season in uplands. Due to water availability, their production cycle started in May and ended in October. The Lao Cai Seed Centre tended to deliver them with Seng $\mathrm{Cu}$ rice seeds that they harvested in the lowlands in June only.
Consequently, upland growers still used mainly home-made seeds to cultivated and certified subsidized seeds for food.

As described previously, the TPC attempted to manage the quality of SC rice through (i) finance in advance high-quality inputs for farmers via contract farming; (ii) collection fresh paddy in the field and pay by cash; and (iii) using modern machinery system. Therefore, TPC always had high credit demand from commercial banks. TPC's total assets reached 6.4 billion Vietnam Dong (VND) with an equity capital of 3.75 billion VND (55\%). Based on the value of collateral (i.e., land use certificate) assessed by VBARD, TPC borrowed 2 billion VND with an interest rate of $11.8 \%$ per year. TPC would need to borrow a short-term loan within 5 months at the harvesting time (May to July and September to October). The remaining amount was financed by family members, private money lenders, and other enterprises. However, all these financing sources still were short-term and TPC had to pay back anytime, therefore, TPC could not proactively use the borrowed money. With 700 tons of paddy collected, this volume just used less than $30 \%$ of TPC's machinery capacity. This under utility led to a high depreciation cost and a low profit.

Small collectors and large collectors, on the other hand, borrowed money from banks and 
received an average of $83.0 \%$ and $75.0 \%$ of the requested amount, respectively (Table 2). Compared to other participants, these satisfied rates were higher, meanwhile their performances were poorer than other chain actors.

The credit gap among the demand of chain actors and their obtained loan size was explained by banks' credit provision and the strict riskavoidance strategy. As regulated by the Decree No. 55/2015/ND-CP, farm households could borrow from VBARD the amount of up to 50 million VND without collateral. Moreover, farm households having a contract with a purchasing enterprise could take a non-collateral loan of up to 100 million VND. In addition, the Government issued Decree No. 98/2018/ND-CP (formerly Decision No. 62/2013/QD-TTg) to stimulate linkages between producers and enterprises, in which agribusinesses were also facilitated to gain access to bank credit. However, in practice, in order to minimize risks, VBARD required collateral, like the land-use certificate (LUC); they lended up to $70 \%$ of the LUC's value based on the Government's regulation or up to $50 \%$ of the value estimated by the land market price. Consequently, nearly all chain actors (producers, collectors, and TPC) faced credit constraints related to collateral. Although the SC rice chain, especially TPC and producers linked with TPC, had high potential, VBARD's decision-making still relied on collateral.

In Lao Cai, a provincial project aimed to provide LUCs to all households since 2014, which belonged to the national land titling program nationwide. Until 2019, the project had not delivered any LUCs to households. The process of obtaining LUCs in Vietnam took time and was complicated due to the perpetual splitting of family plots. Many adults got married and established an independent family, but they did not obatain LUCs yet. As a result, 2-4 households owned one family LUC together; therefore, only one household could use the LUC as collateral. In uplands, local farmers had to face more credit constraints than lowlanders. In-depth interviews with VBARD's representatives showed that lending on upland areas facede higher transaction costs, higher natural risks, and lower value at the real-estate market. These are the reasons why bank officials consider lending to upland farmers to be riskier than lending to lowland farmers.

Besides constraints related to collateral, social and human capital also became credit constraints of many farmers. Both banks, VBARD and VBSP, disbursed loans to farmers mainly by the lending group method; in which, the assessments of local authorities (the leader of lending group, the head of the village, the head of Mass Organization, and the representative of the commune) played a crucial role in screening the loans before disbursement and banks' decision-making. Claudio (2017) also indicated that lending group assessments led to difficulties for bank officers to evaluate applicants (i.e., they "look the same") and to make the right decisions on credit disbursement.

Concerning human capital, which was the third factor affecting credit access, lowlanders had more advantages than uplanders. For example, they had higher educational levels, more labour and fewer dependents, more diversity of non-farm income, and higher available financing as the bank's requirement (Lam et al., 2018). Dufhues (2007) also concluded that credit constraints of farmers in mountainous areas of Vietnam were linked with low/none of the following three types of capital: physical (collateral), social (network among their community), and human capital (education, knowledge, and skills, etc.). The participation of VBARD in the chain was able to help remove various financial challenges and promote their economic performance that was limited and the effectiveness that was still low. In doing so, VBARD needs to change the mind-set to focus more on potential agricultural chains, like the Seng $\mathrm{Cu}$ rice chain, and assess directly the repayment capability of customers through reliable information, not just focus on collateral as currently.

To sum up, this study shows that difficult banking access (i.e., external financial sources) seems to be the biggest obstacle for SC chain actors to reach their optimal performance. Thus, improving credit access is considered as the entry point for breaking the cycle: low investment, low 
productivity, low efficiency, and low income/profit. Indeed, financial availability can help farmers to optimally apply inputs in terms of quantity, quality, and appropriate time. Similarly, TPC can also enhance efficiency and increase income by expanding farming contracts with farmers, purchasing the volume of paddy desired, as well as developing marketing channels (e-commerce, retailing, and wholesaling). For other large buyers, they can improve the processing machine system to improve SC rice quality and reduce wastage. To access banking credit, it is necessary to collaborate among relevant actors, including chain actors (farmers and agribusinesses), banks, and the public sector, which is presented in the underlying implications.

\section{Conclusions and Implications}

\section{Conclusions}

It is a common belief that the right finance at the right time contributes to greater efficiency and better quality of agricultural products; hence, increased incomes of relevant chain participants. This is clearly seen in the case of SC rice, where almost all chain actors had high financial needs but their credit demands had not been met. Indeed, they faced financial constraints due to a lack of collateral, and the strict risk-avoidance strategy of the banks, especially VBARD.

Overall, $85 \%$ of the 160 SC rice producers had financial demands, while $71 \%$ successfully applied for a bank loan with an average amount of 26.6 million VND, which was lower than their desired amount (41.2 million VND). Lowland producers obtained a higher loan size than upland producers, 32.2 and 21.1 million VND, respectively. Lowlanders have more advantages in funding their rice cultivation, not only having higher self-financing ability, but also having easier access to bank credit and in-kind credit provided by enterprises (i.e., input trade credit and contract-farming).

By contrast, upland producers needed both short-term credit for commercial inputs and longterm credit for buying livestock and maintaining the irrigation system of their terraced plots.
Unfortunately, they received smaller credit volume than the amount that they desired. They often bought livestock, followed by goods for consumption, and then, agro-inputs, including $\mathrm{SC}$ rice seeds. Currently, the home-made inputs account for $66 \%$ of the production cost; neither their investments nor productivity and income have improved clearly. Many households were worried about how they would repay their debts, which implies the non-repayment risk of banks.

Likewise, TPC, the leading actor in the chain, needs more capital to enlarge contracts with producers, and consequently increasing paddy collected, which would allow them to maximize the use of their machines. TPC collects fresh paddy and makes payments in the field to prevent growers from mixing ordinary rice with $\mathrm{SC}$ rice and from breaking the contract by sideselling. The five months from harvest till sale, TPC would need 6 billion VND, but they could only borrow 2 billion VND. To compensate for this deficit, TPC partly fills its financial shortage by borrowing money from private lenders who charge a much higher interest rate. This does not only reduce the profit of TPC, but also keeps the benefit of farmers being low. In contrast, the small and large collectors face constraints in accessing credit to build warehouses and fund part of their trade.

\section{Implications}

An effective value chain financing depends on four actors, including: (1) producers; (2) agribusinesses; (3) rural banks; and (4) policymakers. Therefore, the paper suggests relevant recommendations for these key actors as follows.

To handle difficulties in accessing banking credit, farmers' creditworthiness needs to be assessed by banks. To do that, they have to improve their repayment capability through their appropriate farming practices and financial management. Besides this, farmers must comply with the contractual agreements signed with banks and/or enterprises, especially the term of the appropriate loan use.

To enhance their creditworthiness, agribusinesses need to reduce their three existing weaknesses by: (i) Standardizing the financial reports according to the current regulations; (ii) 
Using more banking service in transactions, which allows banks to capture cash flows of agribusiness; and (iii) Improving the management capability and the effectiveness of loan use.

Rural banks should focus on their legal target customers, namely farmers, agribusinesses, and agriculture allied activities. Rural banks also need to participate in the chain and assign credit officer(s) to gather accurate information about the main key chain actors and to estimate their creditworthiness based on the repayment capability of individual actors as well as the potential of the whole chain.

To date, the Vietnamese Government issued the Decree No. 98/2018/ND-CP regarding incentive policies for value chain linkages among farmers, enterprises, and other chain actors. This regulation, however, still does not mention the participation of rural banks in the chain, especially VBARD. Practically, financial availability in the chain does not change without external funds from banks, and chain actors often need credit access to optimize their performance. Therefore, we suggest that the public sector needs to enact new legal framework that requires/encourages the participation of banks in the chain.

\section{Acknowledgments}

The authors would like to thank two anonymous reviewers for their careful reading and valuable comments on the research topic. The analysis expressed here is the authors' alone.

\section{References}

AfDB (2013). Agricultural Value Chain Financing (AVCF) and Development for Enhanced Export Competitiveness. Retrieved from https://www.afdb.org/fileadmin/uploads/afdb/Docum ents/Project-and-

Operations/Agricultural_Value_Chain_Financing_A VCF_and_Development_for_Enhanced_Export_Co mpetitiveness.pdf on May 10, 2017.

Claudio G.-V. (2017). The barriers to agricultural financing and the emergence of new models of financial intermediation for the sector. In: Emilio Hernández (Ed.) Innovative risk management strategies in rural and agriculture finance - The Asian experience. 15-28.
Retrieved from http://www.fao.org/3/a-i6940e.pdf on August 6, 2018.

Coates M., Kitchen R., Kebbell G., Vignon C., Guillemain C. \& Hofmeister R. (2011). Financing agricultural value chains in Africa: A synthesis of four country case studies. Making finance work for Africa. EschbornGermany: Deutsche Gesellschaft für Internationale Zusammenarbeit [GIZ]. Retrieved from http://www.fao.org/sustainable-food-valuechains/library/details/en/c/267127/ on August 9, 2017.

Cochran W. G. (1977). Sampling techniques ( $3^{\text {rd }}$ Edition). John Wiley \& Sons. New York, United State. 448 pages.

De La O Campos A. P., Villani C., Davis B. \& Takagi M. (2018). Ending extreme poverty in rural areas Sustaining livelihoods to leave no one behind. Rome, FAO. 84 pages. Retrieved from http://www.fao.org/3/CA1908EN/ca1908en.pdf on March, 2019.

Dufhues T. (2007). Accessing rural finance: The rural financial market in Northern Vietnam. Studies on the Agricultural and Food Sector in Central and Eastern Europe. etrieved from https://www.researchgate.net/publication/46472781_ Accessing_rural_finance_The_rural_financial_market _in_Northern_Vietnam on May 5, 2017.

Emerson R. M., Fretz R. I. \& Shaw L. L. (1995). Writing ethnographic fieldnotes $\left(2^{\text {nd }}\right.$ ed.). University of Chicago Press, United State.

FAO (1995). History of the credit revolving fund. Retrieved from http://www.fao.org/3/AC576E/AC576E02.htm on May 14, 2019.

FAO \& ADA (2016). Innovations for inclusive agricultural finance and risk mitigation mechanisms -The case of Tamwil El Fellah in Morocco, by Ramirez, J. \& Hernandez, E. Rome, Italy. Retrieved from http://www.fao.org/3/a-i6166e.pdf on September 20, 2017.

Fetterman D. M. (2009). Ethnography: Step-by-step (Applied Social Research Methods) (3 ${ }^{\text {rd }}$ Edition). 200 pages. Sage Publications, United State.

GRiSP (2013). Rice almanac, Source book for one of the most important economic activities on earth (Fourth edition). Los Baños (Philippines): International Rice Research Institute. 283 pages. (Global Rice Science Partnership). Retrieved from http://books.irri.org/9789712203008_content.pdf on August 19, 2018.

GSO (2017). Statistical Yearbook of Vietnam: SocialEconomical Data from 1990 to 2017. General Statistis Office. Retrieved from https://www.gso.gov.vn/default_en.aspx?tabid=515\&i $\mathrm{dmid}=5 \& \mathrm{ItemID}=18533$ on May 6, 2018 (in Vietnamese).

GSO (2018). Results of the Vietnam Household Living Standard Survey (VHLSS) 2018. General Statistis Office. Vietnam. Retrieved from 
https://www.gso.gov.vn/wpcontent/uploads/2020/05/VHLSS2018.pdf on May 10, 2018 (in Vietnamese).

HLPE (2013). Investing in smallholder agriculture for food security. Retrieved from http://www.fao.org/3/ai2953e.pdf on May 10, 2017.

Vi Huyen (2018). Special rice map in Vietnam. Retrieved from https://vnexpress.net/thoi-su/ban-do-cac-loaigao-dac-san-o-viet-nam-3768497.html on March 23, 2019 (in Vietnamese).

Kelly D. (2005). Power and participation: participatory resource management in south-west Queensland. Retrieved from https://openresearchrepository.anu.edu.au/bitstream/1885/47415/13/01fro nt.pdf on September 12, 2019.

Lam B. T., Cuong T. H., Azadi H. \& Lebailly P. (2018). Improving the Technical Efficiency of Sengcu Rice Producers through Better Financial Management and Sustainable Farming Practices in Mountainous Areas of Vietnam. Sustainability. 10(7): 1-19. Retrieved from https://doi.org/10.3390/su10072279 on August $22,2018$.

Lam B. T., Cuong T. H., Ho T. M. H., Eiichi K. \& Philippe L. (2019a). Realisation of Higher Value Added of Seng $\mathrm{Cu}$ Rice Value Chain in Vietnam. 52-86. Retrieved from https://www.eria.org/uploads/media/8.RPR_FY2018_ 05_Chapter_3.pdf on March 5, 2019.

Lam B. T., Hop H. T. M., Philippe B., Dogot T., Tran H. C. \& Lebailly P. (2019b). Impacts of Credit Access on Agricultural Production and Rural Household's Welfares in Northern Mountains of Vietnam. Asian Social Science. 15(7): 119-133. Retrieved from http://www.ccsenet.org/journal/index.php/ass/article/v iew/0/39949 on September 7, 2019.

Miller C. (2012). Agricultural value chain finance strategy and design: Technical Note. Retrieved from https://www.ifad.org/en/web/knowledge/publication/a sset/39181165 on December 9, 2017.

Miller C. \& Jones L. (2010). Agricultural value chain finance: Tools and lessons. Food and Agriculture Organization. Retrieved from http://www.fao.org/docrep/017/i0846e/i0846e.pdf on December 10, 2017.

Miyata S., Minot N. \& Hu D. (2009). Impact of contract farming on income: linking small farmers, packers, and supermarkets in China. World Development. 37(11): 1781-1790. Retrieved from https://doi.org/10.1016/j.worlddev.2008.08.025 on September 12, 2018.

Olomola A. S. (2010). Models of contract farming for propoor growth in Nigeria. IPPG Briefing Note. Retrieved from

https://assets.publishing.service.gov.uk/media/57a08b18 ed915d3cfd000b1e/bp34.pdf on September 12, 2018.

Rapsomanikis G. (2015). The economic lives of smallholder farmers: An analysis based on household data from nine countries. Food and Agriculture Organization of the United Nations, Rome. Retrieved from http://www.fao.org/3/a-i5251e.pdf on March 22, 2019.

Saigenji Y. \& Zeller M. (2009). Effect of contract farming on productivity and income of small holders: The case of tea production in North-Western Vietnam. Retrieved from https://www.researchgate.net/publication/228542523_ Effect_of_contract_farming_on_productivity_and_inc ome_of_small_holders_The_case_of_tea_production _in_north-western_Vietnam on March 10, 2019.

Springer-Heinze A. (2018). ValueLinks 2.0. Manual on Sustainable Value Chain Development, GIZ Eschborn, 2 volumes. Volume 1. Retrieved from https://www.valuelinks.org/material/manual/ValueLin ks-Manual-2.0-Vol-1-January-2018.pdf on December $12,2018$. 